\title{
Response to "Pay Attention to Blood Pressure and Oxygen Supply for Neurocritically III Patients: Each Pathology Deserves a Specific Treatment"
}

\author{
Jaana Humaloja ${ }^{1 *} \mathbb{D}$, Erik Litonius ${ }^{2}$ and Markus B. Skrifvars ${ }^{1}$
}

(c) 2021 The Author(s)

We thank Schmitt and colleagues for their valuable viewpoints on our recent paper on the association of oxygen and blood pressure with outcome in neurocritically ill patients [1]. We agree that the study population is heterogenous, with multiple types of brain injury populations (traumatic brain injury [TBI], ischemic stroke, intracranial hemorrhage, subarachnoid hemorrhage $[\mathrm{SAH}]$, and cardiac arrest [CA]). The pathophysiology and mechanisms underlying the initial brain injury are different, but similarities in disease mechanisms and mechanisms underlying the actual neuronal cell death do exist [2]. Local or global reduction in cerebral blood flow, possible ischemia, and metabolic changes occur after brain hemorrhage, hypoxic-ischemic brain injury, and traumatic brain injury. Inflammation as well as swelling and tissue edema are associated with all neuronal injury types. Neuronal tissue vulnerability to secondary injuries is increased in all of the conditions. Hypotension will reduce brain perfusion irrespective of the cause of autoregulation dysfunction. Also note the very loosely specified blood pressure targets recommended for these different conditions: TBI (systolic blood pressure $[\mathrm{SBP}]>100 \mathrm{mmHg}$ ), CA (mean arterial pressure [MAP] $>65 \mathrm{mmHg}$ and $\mathrm{SBP}>90 \mathrm{mmHg}$ ), and $\mathrm{SAH}$

\footnotetext{
*Correspondence: jaana.humaloja@outlook.com

1 Department of Emergency Care and Services, University of Helsinki and Helsinki University Hospital, Helsinki, Finland

Full list of author information is available at the end of the article
}

This article is related to the original article available at https://link.sprin ger.com/article/https://doi.org/10.1007/s12028-020-01178-w. This article is the response to Letter to the Editor available at https://doi.org/10.1007/ s12028-021-01212-5.

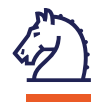

\section{Springer}

$(\mathrm{SBP}<160 \mathrm{mmHg})$ all refer to a similar blood pressure range [1]. The oxygen demand can vary between patients but is likely heterogenous between the individuals irrespective of their brain injury type. The actual partial pressure of arterial oxygen blood peripheral oxygen saturation targets are not specified for any of these conditions; $\mathrm{SpO}_{2}$ targets are specified only for ischemic stroke (>94\%) and CA (94-98\%). There is no clear evidence that these cohorts would need very different treatment targets during the initial care. Indeed, avoiding hypoxia and hypotension are likely to be important in all these patient types. When planning the analysis, we decided to study the brain injury population as a whole and complement the analysis with relevant subgroup assessments. In these analyses with the performed sensitivity analysis separating the different diagnosis cohorts with logistic regression analysis and local regression curves, we found the results to be consistent with those obtained from the analysis of the whole study population.

As stated by Schmitt and colleagues, $\mathrm{PaO}_{2}$ and MAP are not the only measures to determine brain tissue oxygenation. For example arterial $\mathrm{CO}_{2}$, intracranial pressure, and blood hemoglobin concentration are all factors in oxygen delivery to the brain [3]. Nevertheless, MAP is a major determinant of cerebral perfusion pressure, and there is evidence that increasing $\mathrm{PaO}_{2}$, regardless of already $100 \% \mathrm{O}_{2}$-saturated blood hemoglobin, increases partial pressure of brain oxygen $\left(\mathrm{PbO}_{2}\right)$ [4]. Similar findings have been found when manipulating oxygen in patients with cardiac arrest. Our registry only contained certain discrete values of MAP (the worst value recorded during the initial $24 \mathrm{~h}$ in the intensive care unit) and $\mathrm{PaO}_{2}$ 
(the value associated with the lowest $\mathrm{P} / \mathrm{F}$ ratio) available, and instead of exact measures the values should be seen as surrogates to categorize patients into groups based on their hemodynamic and oxygenation conditions. Altogether, we agree that our study has limitations; for example, actual measurements of intracranial pressure, arterial $\mathrm{CO}_{2}$, and $\mathrm{PbO}_{2}$ would have been of great value, but unfortunately these important variables are not routinely collected in the registry. Importantly, we agree that a study such as this can only find associations between variables and therefore causative mechanisms can only be speculated. There is no doubt that further studies incorporating more refined measures of brain oxygenation are required in patients with different types of brain injury [5].

\section{Author details \\ ${ }^{1}$ Department of Emergency Care and Services, University of Helsinki and Helsinki University Hospital, Helsinki, Finland. ${ }^{2}$ Division of Anesthesiology, Department of Anesthesiology, Intensive Care and Pain Medicine, University of Helsinki and Helsinki University Hospital, Helsinki, Finland.}

\section{Source of support}

None.

\section{Conflicts of Interest}

None.

\section{Open Access}

This article is licensed under a Creative Commons Attribution 4.0 International License, which permits use, sharing, adaptation, distribution and reproduction in any medium or format, as long as you give appropriate credit to the original author(s) and the source, provide a link to the Creative Commons licence, and indicate if changes were made. The images or other third party material in this article are included in the article's Creative Commons licence, unless indicated otherwise in a credit line to the material. If material is not included in the article's Creative Commons licence and your intended use is not permitted by statutory regulation or exceeds the permitted use, you will need to obtain permission directly from the copyright holder. To view a copy of this licence, visit http://creativecommons.org/licenses/by/4.0/.

\section{Publisher's Note}

Springer Nature remains neutral with regard to jurisdictional claims in published maps and institutional affiliations.

Received: 17 February 2021 Accepted: 18 February 2021

Published online: 22 March 2021

\section{References}

1. Humaloja J, Skrifvars MB, Raj R, Wilkman E, Pekkarinen PT, Bendel S, et al. The association between arterial oxygen level and outcome in neurocritically ill patients is not affected by blood pressure. Neurocrit Care. 2021. https://doi.org/10.1007/s12028-020-01178-w.

2. Bramlett HM, Dalton DW. Pathophysiology of cerebral ischemia and brain trauma: similarities and differences. J Cereb Blood Flow Metab. 2004;24(2):133-50.

3. Vavilala MS, Lee LA, Lam AM. Cerebral blood flow and vascular physiology. Anesthesiol Clin North Am. 2002;20(2):247-64.

4. Rosenthal G, Hemphill JC, Sorani M, Martin C, Morabito D, Obrist WD, et al. Brain tissue oxygen tension is more indicative of oxygen diffusion than oxygen delivery and metabolism in patients with traumatic brain injury. Crit Care Med. 2008;36(6):1917-24.

5. Sekhon MS, Smielewski P, Bhate TD, Brasher PM, Foster D, Menon DK, et al Using the relationship between brain tissue regional saturation of oxygen and mean arterial pressure to determine the optimal mean arterial pressure in patients following cardiac arrest: a pilot proof-of-concept study. Resuscitation. 2016:106:120-5. 